\title{
Factors Influencing Loan Portfolio Quality of Microfinance Institutions in Haiti
}

\author{
Rocheny Sifrain \\ Independent Researcher, Port-au-Prince, Haiti \\ Email: rsifrain@gmail.com
}

How to cite this paper: Sifrain, R. (2022). Factors Influencing Loan Portfolio Quality of Microfinance Institutions in Haiti. Journal of Financial Risk Management, 11, 95115.

https://doi.org/10.4236/jfrm.2022.111005

Received: January 23, 2022

Accepted: March 1, 2022

Published: March 4, 2022

Copyright $\odot 2022$ by author(s) and Scientific Research Publishing Inc. This work is licensed under the Creative Commons Attribution International License (CC BY 4.0).

http://creativecommons.org/licenses/by/4.0/

\begin{abstract}
This paper examines factors affecting loan portfolio quality of MFIs in Haiti, over the period of October 2016 to September 2021, using a sample of four non-cooperative MFIs (MFI1, MFI2, MFI3 and MFI4) offering individual loans. This study applies the Ordinary Least Squares (OLS) regression to estimate the effects of two macroeconomic variables (exchange rate and inflation rate) and two micro-variables (loan amount per borrower and gross loan portfolio) on loan portfolio quality, measured by portfolio at risk over 30 days (PAR30). One statistical model has been specified for all MFIs and one statistical model has been specified for each MFI individually. Overall, the results show that portfolio at risk of MFIs can increase with the depreciation of local currency and as the inflation rises; but the results are not statistically significant. However, distinctively, the findings of MFI1 and MFI3 indicate a positive and statistically significant association with the exchange rate, while the output of MFI4 suggests a negative and insignificant relationship with the exchange rate. Only the result of MFI2 indicates a negative and insignificant relationship between the loan portfolio quality and the inflation rate. On the other hand, the growth of the loan portfolio affects adversely and significantly the loan portfolio at risk of MFIs globally and individually, except MFI3 that indicates a negative and insignificant association with the gross loan portfolio. Among the four MFIs, only the finding of MFI4 shows that the loan portfolio quality would significantly improve as the amount disbursed per borrower increases. In contrast, for the rest of MFIs, as the loan amount increases, the PAR30 would rise. Some implications can be drawn in light of these findings. Authorities should create a promising macroeconomic environment that would help MFIs to limit their credit risk. Moreover, MFIs should reinforce their credit analysis, collection procedures and practices, in order to ensure their loan portfolio growth, without compromising its quality.
\end{abstract}


Keywords

Loan Portfolio Quality, Ordinary Least Square (OLS), Microfinance Institutions (MFIs), Haiti

\section{Introduction}

Since early 1990s microfinance has been claimed to be a means to release the productive capacities of poor people relying on self-employment (Hulme \& Mosley, 1996). In 2013, Muhammad Yunus asserted that microfinance would transform borrowers' businesses by providing them with capital, which would increase their incomes and consequently eradicate poverty (Singh, 2018). Due to their vulnerability, poor people could not have access to the traditional credit market. Lack of collateral and formal documents constitutes among others elements of constraints that poor people are faced with. Information asymmetries are pointed out to be a constraint of standard lending contracts, indicating that banks did not possess all required information to assess credit risk of borrowers (Stiglitz \& Weiss, 1981). Microfinance has therefore been considered to be the tool which introduced innovations in credit contracts, mostly group lending and installment lending (Armendáriz \& Morduch, 2000). Microfinance shows more largely a new way of development intervention, one that deemphasizes governments as the central actors and turns to market-mechanisms to deliver services through diverse organizations incorporating social and financial goals (Conning \& Morduch, 2011).

Globally, the microfinance sector has realized important progress during the past decades on the path to achieving its goal of reducing poverty around the world. Microfinance has shown that poor people are sustainable customers, established numerous robust institutions centered on poor people's finance, and attracted the interest of private investors. In 2018, 139.9 million borrowers benefited from the services of microfinance institutions (IMFs) against 98 million in 2009, which represents a growth of $42.8 \%$ in less than 10 years. Of these 139.9 million borrowers, $65 \%$ are rural borrowers. The gross loan portfolio was estimated at USD 124.1 billion at the same period. Compared to 2017, MIFs recorded a yearly growth of $8.5 \%$ of their gross loan portfolio (Convergences, 2019).

In Haiti, where nearly $70 \%$ of the population are poor and $50 \%$ are extremely poor, with a low income per capita of USD 1149.50 in 2020 (World Bank, 2021), the informal economy and the working poor dominate the whole economy. These poor people are often excluded from accessing financial services from the formal financial system, mostly due to economic reasons, such as lack of collateral. To satisfy their financing needs, Haitian micro entrepreneurs are often obliged to turn to loan sharks with high interest rates. This situation promoted the emergence of a new financing technology adapted to the needs of Haitian micro 
entrepreneurs, which is microfinance. Indeed, knowing the effectiveness of micro enterprises, several categories of institutions have embarked on the microfinance sector in order to make small funds available to micro entrepreneurs. The elimination in 1995 of the interest rate cap of $22 \%$ constituted one of the incentives for several Haitian banks to integrate the microfinance sector by creating a dedicated subsidiary (Lustin, 2005).

Over the last two decades, the contribution of these institutions to reduce the financial exclusion gap by providing those ignored by the formal financial system with access to affordable capital has been significant. The financial services they offer play an important role in poverty alleviation in the country. In spite of all the political, social, and environmental disturbances which occurred in Haiti, according to. DAI Finance Inclusive (2019), the number of clients recorded an increase of $6.8 \%$ in two years, passing from 1.1 million clients in 2017 to 1.2 million clients in 2019. On the contrary, during the same periods, the number of borrowers decreased of 2.37\%, passing from 272,082 in 2017 to 265,639 in 2019. In terms of total amount of loans outstanding, an increase of $11.21 \%$ was recorded in two years (USD 222.2 million in 2019 compared to USD 199.8 in 2017). Despite their progress and contribution to income generation, access to sustainable financial services and resilience of Haitian micro entrepreneurs, MFIs continue to tackle with a deteriorating loan portfolio quality. In 2019, the MIFs recorded a rate of $6.88 \%$ of their portfolio at risk (PAR) $>30$ days, compared to $6.32 \%$ in 2018 , i.e. a yearly deterioration of almost $10.00 \%$ (DAI Finance Inclusive, 2019). The rates of PAR > 30 days recorded both in 2018 and 2019 are higher than the internationally accepted threshold which is typically less than $5.00 \%$. This poor performance is seen as an increasing concern for the MFIs, because their loan portfolio represents their main asset and also their major source of risk (MicroRate, 2014). Therefore, the loan portfolio quality is very critical. The sustainability of the MFIs depends on a good portfolio quality.

However, scholarly studies carried out on the Haitian microfinance sector have mainly focused on poverty outreach to better understand the poverty profile of microfinance clients. These were interested in knowing whether MIFs reached out the poor or not (Dewez, HornWelch, \& Devaney, 2003; Julien \& Cadet, 2013). Other investigations emphasized the impacts of microfinance on microenterprise performance (Ciguino \& Paul, 2016; Ciguino \& Paul, 2021); the role of microfinance in poverty alleviation (Lustin, 2005). Authors like Paul, Garrabé and Daméus (2011) studied the impact of the credit granting policy on borrower behavior. The topic of loan portfolio quality has been though neglected in scholarly research in Haiti, while it is vital to the MFIs, mostly over the past five years, where managing the loan portfolio quality has become more and more challenging. Thus, lenders and practitioners are eager to identify the main drivers of the loan portfolio quality in the Haitian context.

The deterioration of the loan portfolio quality observed during recent years in the Haitian microfinance market might be attributed to several factors. But, the aim of this paper is to assess the influence of the exchange rate, the inflation rate, 
the loan amount per borrower and the gross loan portfolio on the loan portfolio quality of the microfinance institutions in Haiti. This research emphasizes the following questions:

1) Does the exchange rate HTG/USD affect the loan portfolio quality of Haiti's microfinance institutions?

2) Does the inflation rate affect the loan portfolio quality of microfinance institutions in Haiti?

3) How does the loan amount per borrower affect the loan portfolio quality of a microfinance institution?

4) Does the gross loan portfolio impact the loan portfolio quality of the Haitian microfinance institutions?

The rest of this paper is structured as follows: Section 2 reviews the theory and the relevant literature related to our research topic; Section 3 describes the data and the method used to carry out our statistical analysis; Section 4 presents and discusses the main findings of the research; and Section 5 concludes this study.

\section{Theoretical and Literature Review}

\subsection{Modern Portfolio Theory}

This study used the Modern Portfolio Theory (MPT), attributed to Harry Markowitz (1952). The MPT is considered to be one of the most important and powerful economic theories in finance and investment. This theory is particularly widely used in portfolio and risk management. The MPT refers to an investment theory that allows investors to select and build assets portfolios that maximize expected return for a given level of risk. The theory assumes that investors are risk-averse. For a given level of expected return, they always prefer the least risky portfolio. The selection and the construction of investment portfolios are then based on maximizing the expected return and simultaneously minimizing the investment risk (Fabozzi et al., 2002). The MPT argues that rational investors diversify their portfolios in order to optimize them (Pfaff, 2012). This can be achieved by choosing to use different amounts of investments which are carefully selected while taking into account how the investment is likely to be affected by the other elements of the portfolio rather than choosing individual securities (Francis \& Kim, 2013). Each security has its own risks, which is higher than that of a portfolio containing diverse securities (Pfaff, 2012). The risk component of MPT can be measured, using various mathematical formulations, and reduced through the concept of diversification which aims to suitably select a weighted collection of investment assets that together show lower risk factors than investment in any individual asset. Diversification is known as the central concept of the MPT (Mangram, 2013).

Microfinance institutions (MFIs) which target low income people have to balance the different types of risks within their portfolio (Adugna, 2014). Credit risk, interest rate risk, and liquidity risk are the common risks faced by MFIs (Adugna, 2014). Credit risk results from the unwillingness or inability among 
borrowers to repay their loans. Consequently, MFIs portfolio deteriorates, revenues decrease, and operating expenses increase. The risk that affects Haitian MFIs may include the risk of default, untimely repayments by borrowers, weakness in borrowers' creditworthiness assessment, and inadequate knowledge on how to efficiently manage collection activities. The more the macroeconomic and socio-political environment of the microfinance sector worsens in Haiti, the greater this risk and the higher is the likelihood of experiencing a deteriorating loan portfolio.

\subsection{Literature}

Loan portfolio constitutes the core investment of MIFs. The objective of shareholders is to optimize their profits with a minimal portfolio at risk according to modern portfolio theory. Thus, identifying factors that can affect loan portfolio quality of MFIs has become an important issue for practitioners and investors. In the light of this, scholars (Jote, 2018; Agasha et al., 2020; Mikir \& Milkessa, 2020; Dung, 2020) investigated determinants of loan portfolio quality of MFIs. The following subsections summarize previous studies carried out on relationships between loan portfolio quality and the two macroeconomic factors (exchange rate and inflation rate) and the two specific variables to MFIs (loan amount by borrower and gross loan portfolio) targeted by this study.

\subsubsection{Loan Portfolio Quality}

Since the loan portfolio is the foremost asset of a microfinance institution, it constitutes its main source of risk. In general, loans granted by MFIs are not backed by collateral. As a result, the loan portfolio quality is very central to MFIs. In the microfinance industry, there are four indicators commonly used to measure loan portfolio quality: Portfolio at Risk (PAR), Write-off Ratio, Impairment Expense Ratio, and Risk Coverage Ratio. The PAR measures the portion of the loan portfolio affected by delinquency as a percentage of the total portfolio. The Write-Off Ratio is obtained by dividing total write-offs for the period by the period's average gross loan portfolio. The Impairment Expense Ratio, also known as the Provision Expense Ratio, is determined by dividing the impairment expense for the period by the period's average gross loan. The Risk Coverage Ratio is calculated by dividing impairment reserve by the outstanding balance of loans that are in arrears over 30 days (PAR30). The PAR is the commonly used measure of portfolio quality in the microfinance sector. It does not underestimate risk and is comparable across institutions (MicroRate, 2014). For a microfinance institution, a loan is usually considered to be at risk if a payment on the loan is over 30 days late. The lower the PAR30 ratio, the better the loan portfolio quality.

This study investigates factors affecting loan portfolio quality of the Haitian microfinance institutions, using exchange rate, inflation rate, loan amount per borrower, and gross loan portfolio. Insights from previous related studies helped draw the following conclusions. 


\subsubsection{Loan Portfolio Quality and Exchange Rate}

While many studies examined the influence of exchange rate on non-performing loans (NPL) of commercial banks across the world, literature on the effects of the foreign exchange rate on credit risk of microfinance institutions look limited. Since commercial banks and microfinance institutions generally target different clientele with different characteristics, the exchange rate might affect differently their respective loan portfolio quality. The reactions of the clienteles to a change of the exchange rate could differ. So, reviewing literature analyzing the impacts of the exchange rate on non-performing loan of commercial banks might not be convenient to this paper. However, due to the lack of literature on the microfinance sector, it is useful to note some conclusions drawn from studies related to the banking sector, in order to have a general view about the effects of exchange rate on loan portfolio quality. Examining the macroeconomic variables on the non-performing loans (NPL) in the Albanian banking sector, Shingjergji (2013) found that the real effective exchange rate has a positive relationship with NPL levels. Khemraj and Pasha (2009) revealed that the real effective exchange rate has a positive impact on NPLs in the Guyanese banking sector, indicating that with an appreciation in the local currency, the NPLs of commercial banks are likely to increase. Akinlo and Emmanuel (2014) also found that exchange rate has positive influence on non-performing loans in Nigeria, suggesting that exchange rate appreciation might contribute to a deterioration of loan portfolio quality of banks. Heiden, Klein and Zwergel (2013) showed that exchange rate depreciation is associated with lower banks assets quality, mainly in countries with widespread currency mismatches.

\subsubsection{Loan Portfolio Quality and Inflation Rate}

Numerous studies have focused on the effect of inflation on non-performing loans of the banking sector. On the contrary, very little work has been carried out in the microfinance industry. However, the impact of inflation rate on loan portfolio quality of MFIs was investigated by (Hitchcock, 2014; Necesito, 2016). The finding shows that the association of loan portfolio quality of Philippine MFIs with the inflation rate is positive and significant, indicating that the inflation is a factor that strongly affects the portfolio at risk of MFIs (Necesito, 2016). Conversely, using different measures of loan portfolio quality as dependent variables (among others, PAR30 days and PAR90 days), Hitchcock (2014) indicates that inflation has a strongly negative and significant relationship with all of dependent variables. This suggests that as the inflation rises, the credit risk might decrease. The study also indicates that inflation is significant for for-profit MFIs, but not for non-profit ones. However, the author does not provide any explanations to support this output.

\subsubsection{Loan Portfolio Quality and Loan Amount Per Borrower}

The effect of loan amount per bower on portfolio quality was examined by previous studies (Schreiner, 1999; Vogelgesang, 2003; Papias \& Ganesan, 2009; Se- 
targie, 2013; Pal \& Mitra, 2017). Using data from a Bolivian microfinance institution, Schreiner (1999) estimated the probability of overdue loans. Among other things, results indicated that loan size influence significantly borrowers' repayment behavior. The larger the loan size, the more likely the loan is to be overdue. Vogelgesang (2003) researched repayment determinants for loans from Caja Los Andes, a Bolivian microfinance institution. Results indicated that higher loan sizes (for first loans) increase the likelihood that a loan becomes overdue. Using data of 632 MFIs from 37 countries of the Sub-Saharan African region and employing a GMM technique, Chikalipah (2018) found that credit risk is positively related to loan sizes. The credit risk is more likely to increase with an increase of the loan sizes. However, other related studies carried out by Berger and Udell (1995), Harhoff and Körting (1998), Leeth and Scott (1989) found a negative and statistically significant relationship between credit risk and loan sizes. Other things constant, an increase in the loan sizes might imply a decrease in the credit risk of MFIs.

\subsubsection{Loan Portfolio Quality and Gross Loan Portfolio}

Several studies focused on the impact of the gross loan portfolio on the loan portfolio quality of MFIs. Tehulu and Abegaz (2016) concluded the gross loan portfolio has a negative and significant impact on the credit risk of MFIs, represented by PAR30 days ratio. Other things constant, this result indicates that an increase in the size of loan portfolio will imply a decrease in the credit risk. However, Pal and Mitra (2017) found that the gross portfolio has a positive and significant impact on the loan portfolio quality, using data from 1575 MFIs. This suggests that an increasing loan portfolio is associated with greater portfolio value at risk. With panel data of 15 MFIs in Ethiopia, Teferi (2019) investigated the determinants of loan portfolio quality. The study employed the pooled ordinary least squares and random effects generalized least squares. Findings showed a positive and significant coefficient for outstanding loan ratio with PAR30 days and write-off ratio, two dependent variables used as proxies to measure the loan portfolio quality. This result implies that the more the proportion of loan portfolio to total assets of a MFI increases, the higher the portfolio at risk is likely to be, due to the fact that the magnitude of default loan increases with the size of the loan outstanding.

\section{Data and Methodology}

The study adopted an explanatory research method that is quantitative and hypotheses tested by measuring the correlation between the studied variables using econometric models.

\subsection{Sampling and Data}

This study focuses on factors influencing loan portfolio quality of microfinance institutions in Haiti, using a sample of four non-cooperative MFIs extending in- 
dividual loans ${ }^{1}$ : MFI1, MFI2, MFI3 and MFI4. Their choice is particularly motivated by their significant market shares in the whole Haitian microfinance sector, in terms of gross loan portfolio size. As of September 2021, their portfolio outstanding loans reached USD 126.4 million for a total of 60,562 active loans. The study uses monthly data which were collected from SOGESOL(Société Générale de Solidarité), through the information exchange established among members of ANIMH (Association Nationale des Institutions de Microfinance d'Haït). ANIMH is a group of nine non-cooperative MFIs (https://animhaiti.net/). The macroeconomic (Exchange rate and inflation rate) data were collected from the official website of the Haitian Central Bank (https://www.brh.ht/). The research covers five fiscal years of data, from October 2016 to September 2021, resulting in sixty observations for each variable.

\subsection{Variables and Their Measurement}

This paper examines the impacts of the Exchange rate, the Loan amount per loan officer, the inflation rate and the gross loan; portfolio on the Loan portfolio quality measured by the Portfolio at Risk over 30 days (PAR30) ratio.

\section{Portfolio at Risk > 30 Days Ratio (PAR30)}

The study measures loan portfolio quality by portfolio at risk over 30 days (PAR30) whose researchers indicated the potential for future losses based on current performance (Bitok et al., 2020). This does not undervalue risk and is comparable across MFIs. The PAR30 days indicates that loans are effectively at risk compared to PAR1-30 days. The PAR30 ratio is calculated by dividing the outstanding balance of all loans with arrears over 30 days by the outstanding gross loan portfolio.

\section{Exchange rate (EXR)}

The performance of banks can be affected both directly and indirectly by exchange rate volatility (Keshtgar et al., 2020). The direct effect of exchange rate volatility on banks performance is associated with the banks operating in the foreign exchange related activities. Indirectly, exchange rate volatility impacts the behavior and performance of depositors and borrowers, and unfavorably affects banking risk and banks performance. Exchange rate fluctuation is known as an important factor in explaining the ratio of non-performing loan to total lending of the banks and create credit risk for the banks.

Based on the HTG/USD exchange rate fluctuations over the last five years, it is convenient to examine its impacts on the portfolio quality of MFIs, which serve a large number of Micro, Small and Medium enterprises (MSME) of the informal sector, dominated by trade in imported products. As the exchange rate increases, the price of imported products in terms of local currency increases. This can result in a decrease of goods demand, impacting harmfully MFIs borrowers' capacity to repay their loans. The Exchange rate (EXR) is defined as the local currency (HTG) units per U.S. dollar. Hence, we hypothesize that an increase in ${ }^{1}$ For confidentiality reasons, the real name of the four MFIs under study has been respectively replaced by MFI1, MFI2, MFI3 and MFI4. 
the Exchange rate would critically affect the loan portfolio quality.

\section{Inflation Rate (INFL)}

The rise in price of goods and services in an economy, over a period of time, is known as inflation.

It is calculated as:

$\frac{\text { Current consumer price index }- \text { historical consumer price index }}{\text { Current consumer price index }} \times 100$.

From a theoretical view, the direction of the effect of inflation on credit risk is ambiguous (Necesito, 2016). If the inflation rate rises to hyperinflation levels, the portfolio risk increases. On the contrary, higher inflation may help borrowers if they obtained fixed-rate domestic loans. Hence, the expected relationship of the inflation rate with the portfolio at risk of Haitian MFIs is either positive or negative.

\section{Loan Amount per Borrower (LAB)}

The loan amount per borrower represents the amount disbursed to borrower on average. This variable indicates the level of a borrower's indebtedness. With excess borrowing, a micro-borrower may use more funds for non-productive purposes, and as a result, the surplus generated out of the productive use of the funds may not be sufficient to meet the repayment obligations (Pal \& Mitra, 2017). As a result, the higher the loan amount per borrower, the more likely is the risk to increase.

\section{Gross Loan Portfolio (GLP)}

The gross loan portfolio represents all outstanding principal for all outstanding client loans. It includes current, delinquent and restructured loans. Following Pal and Mitra (2017), Teferi (2019), we hypothesize that a higher gross loan portfolio would be related to a greater portfolio at risk.

Table 1 shows a summary of the description of the four independent variables and their expected relationship with the dependent variable.

\subsection{Research Method}

This study employs the Ordinary Least squares (OLS) regression to estimate factors affecting loan portfolio quality of Haitian MFIs. OLS is a method for estimating the unknown parameters in a linear regression model. This statistical technique allows minimizing the sum of squared vertical distances between the observed responses in the dataset and the responses predicted by linear approximation (Daly \& Frikha, 2016).

This research formulates five equations. These are specified as follows, using logarithmic transformation:

$$
\begin{aligned}
\operatorname{Ln}\left(\text { PAR30 }_{s t}\right)= & \beta_{0}+\beta_{1} \operatorname{Ln}\left(E X R_{t}\right)+\beta_{2} \operatorname{Ln}\left(I N F L_{t}\right)+\beta_{3} \operatorname{Ln}\left(L A B_{s t}\right) \\
& +\beta_{4} \operatorname{Ln}\left(G L P_{s t}\right)+\varepsilon_{s t} \\
\operatorname{Ln}\left(P A R 30_{M F I t}\right)= & \beta_{0}+\beta_{1} \operatorname{Ln}\left(E X R_{t}\right)+\beta_{2} \operatorname{Ln}\left(I N F L_{t}\right)+\beta_{3} \operatorname{Ln}\left(L A B_{M F I t}\right) \\
& +\beta_{4} \operatorname{Ln}\left(G L P_{M F I t}\right)+\varepsilon_{M F 1 t}
\end{aligned}
$$


Table 1. Description of variables and expected relationship.

\begin{tabular}{|c|c|c|c|}
\hline Variable & Measure & \multicolumn{2}{|c|}{ NotationExpected effect } \\
\hline \multicolumn{4}{|l|}{ Dependent } \\
\hline $\begin{array}{l}\text { Portfolio at Risk }>30 \\
\text { days Ratio }\end{array}$ & $\begin{array}{l}\text { Outstanding balance of all loans with arrears more than } 30 \text { days over the } \\
\text { outstanding gross loan portfolio in percent. }\end{array}$ & PAR30 & N/A \\
\hline \multicolumn{4}{|l|}{ Independent } \\
\hline Exchange rate & Local currency (HTG) units per U.S. dollar. & EXR & + \\
\hline Inflation & Inflation rate as measured by the consumer price index & INFL & \pm \\
\hline $\begin{array}{l}\text { Loan Amount per } \\
\text { Borrower }\end{array}$ & $\begin{array}{l}\text { Loan amount disbursed to borrowers on average/Loan size } \\
\text { (Level of indebtedness of borrowers). }\end{array}$ & LAB & + \\
\hline Gross Loan Portfolio & All outstanding principal for all outstanding client loans. & GLP & + \\
\hline
\end{tabular}

$$
\begin{aligned}
\operatorname{Ln}\left({\text { PAR } \left.30_{M F I 2 t}\right)=}\right. & \beta_{0}+\beta_{1} \operatorname{Ln}\left(E X R_{t}\right)+\beta_{2} \operatorname{Ln}\left(I N F L_{t}\right)+\beta_{3} \operatorname{Ln}\left(L A B_{M F I 2 t}\right) \\
& +\beta_{4} \operatorname{Ln}\left(G L P_{M F I 2 t}\right)+\varepsilon_{M F I 2 t} \\
\operatorname{Ln}\left(P A R 30_{M F I 3 t}\right)= & \beta_{0}+\beta_{1} \operatorname{Ln}\left(E X R_{t}\right)+\beta_{2} \operatorname{Ln}\left(I N F L_{t}\right)+\beta_{3} \operatorname{Ln}\left(L A B_{M F I 3 t}\right) \\
& +\beta_{4} \operatorname{Ln}\left(G L P_{M F I 3 t}\right)+\varepsilon_{M F I 3 t} \\
\operatorname{Ln}\left(P A R 30_{M F I 4 t}\right)= & \beta_{0}+\beta_{1} \operatorname{Ln}\left(E X R_{t}\right)+\beta_{2} \operatorname{Ln}\left(I N F L_{t}\right)+\beta_{3} \operatorname{Ln}\left(L A B_{M F I 4 t}\right) \\
& +\beta_{4} \operatorname{Ln}\left(G L P_{M F I 4 t}\right)+\varepsilon_{M F I 4 t}
\end{aligned}
$$

In equation [1], $\operatorname{Ln}\left(P A R 30_{s t}\right)$ denotes the natural logarithmic function of portfolio at risk over 30 days (in \%) of the sector, represented by $s$, which is the sample of the four MFIs (MFI1, MFI2, MFI3 and MFI4) at time $t, \operatorname{Ln}\left(E X R_{t}\right)$ is the natural logarithmic function of the exchange rate HTG/USD at time $t$; $\operatorname{Ln}\left(I N F L_{t}\right)$ represents the natural logarithmic function of inflation rate at time $t$, $L n\left(L A B_{s t}\right)$ denotes the natural logarithmic function of loan amount per borrower of the sector at time $t, \operatorname{Ln}\left(G L P_{s t}\right)$ indicates the natural logarithmic function of gross loan portfolio of the sector; the $\varepsilon_{s t}$ captures the random error of the sector at time $t$. Since credit policy, recovery procedures and practices might be different from an MFI to another, an equation is formulated for each MFI, in order to provide insights for individual MFI, compared to the results of the sector.

In equation [2], $\operatorname{Ln}\left(P A R 30_{M F I 1}\right)$ represents the natural logarithmic function of portfolio at risk over 30 days (in \%) of MFI1 at time $t, \operatorname{Ln}\left(E X R_{t}\right)$ indicates the natural logarithmic function of the exchange rate HTG/USD at time $t$, $\operatorname{Ln}\left(I N F L_{t}\right)$ represents the natural logarithmic function of inflation rate at time $t$, $L n\left(L A B_{M F I t}\right)$ stands for the natural logarithmic function of loan amount per borrower of MFI1 at time $t, \operatorname{Ln}\left(G L P_{M F I t}\right)$ indicates the gross loan portfolio of MFI1 at time $t$, the $\varepsilon_{\text {MFIt }}$ refers to the random error of MFI1 at time $t$. In equation [3], $\operatorname{Ln}\left(P A R 30_{M F I 2 t}\right)$ represents the natural logarithmic function of portfolio at risk over 30 days (in \%) of MFI2 at time $t, \operatorname{Ln}\left(E X R_{t}\right)$ indicates the natural logarithmic function of the exchange rate HTG/USD at time $t, \operatorname{Ln}\left(I N F L_{t}\right)$ 
represents the natural logarithmic function of inflation rate at time $t$,

$\operatorname{Ln}\left(L A B_{M F I 2 t}\right)$ stands for the natural logarithmic function of loan amount per borrower of MFI2 at time $t, \operatorname{Ln}\left(G L P_{M F I 2 t}\right)$ indicates the gross loan portfolio of MFI2 at time $t$, the $\varepsilon_{\text {MFI2t }}$ refers to the random error of MFI2 at time $t$. In equation [4], $\operatorname{Ln}\left(P A R 30_{M F I 3 t}\right)$ represents the natural logarithmic function of portfolio at risk over 30 days (in \%) of MFI3 at time $t, \operatorname{Ln}\left(E X R_{t}\right)$ indicates the natural logarithmic function of the exchange rate HTG/USD at time $t$; $\operatorname{Ln}\left(I N F L_{t}\right)$ represents the natural logarithmic function of inflation rate at time $t$, $L n\left(L A B_{\text {MFI3t }}\right)$ stands for the natural logarithmic function of loan amount per borrower of MFI3 at time $t, \operatorname{Ln}\left(G L P_{\text {MFI3t }}\right)$ indicates the gross loan portfolio of MFI3 at time $t$, the $\varepsilon_{M F I 3 t}$ refers to the random error of MFI3 at time $t$. In equation [5], $\operatorname{Ln}\left(P A R 30_{M F I 4 t}\right)$ denotes the natural logarithmic function of portfolio at risk over 30 days (in \%) of MFI4 at time $t, \operatorname{Ln}\left(E X R_{t}\right)$ indicates the natural logarithmic function of the exchange rate HTG/USD at time $t ; \operatorname{Ln}\left(I N F L_{t}\right)$ indicates the natural logarithmic function of inflation at time $t, \operatorname{Ln}\left(L A B_{\text {MFI } 4 t}\right)$ denotes the natural logarithmic function of loan amount per borrower of MFI4 at time $t, \operatorname{Ln}\left(G L P_{M F I 4 t}\right)$ indicates the gross loan portfolio of MFI4 at time $t$; the $\varepsilon_{\text {MFI } 4 t}$ refers to the random error of MFI4 at time. These regressions are run, using R Software. Ln(LABMFI3t )

\section{Results and Discussion}

This section shows and discusses the statistical results of the study. Descriptive statistics are provided for the whole sample of MFIs, with some evidence for individual MFIs. The estimation results of all MFIs are analyzed. These are followed by an analysis of estimation results of each MFI for a better understanding of the effects of the studied variables on loan portfolio quality at an individual level. The section is ended with regression diagnostics.

\subsection{Descriptive Statistics}

Table 2 displays descriptive statistics for the dependent variable and the explanatory variables for the sample MFIs, represented by MFI1, MFI2, MFI3 and MFI4, over the period under study (October 2016 to September 2021). The average PAR30 ratio is $8.29 \%$, indicating a deterioration of the loan portfolio quality compared to the threshold of $5.00 \%$ which is generally considered as a benchmark for the industry of microfinance. The standard deviation is $2.48 \%$. This indicates that the variability in loan portfolio quality among the MFIs is not so wide. Two of these MFIs (MFI4 and MFI1) have a larger PAR30 ratio than the average PAR 30 ratio of all MFIs while the two others (MFI3 and MFI2) have lower PAR30 ratio. The maximum PAR30 ratio reached also $15.00 \%$. The exchange rate has evolved between 62.2 HTG/1USD and 119.7 HTG/1USD, with an average of 79.23 HTG/1USD and a standard deviation of $15.26 \mathrm{HTG} / \mathrm{USD}$. These values indicate the depreciation of the local currency compared to the US dollar. In addition, the lowest and the highest inflation rate are $-1.20 \%$ and 
Table 2. Descriptive statistics of the data (All MFIs).

\begin{tabular}{ccccccc}
\hline Variable & Notation & Observation & Mean & Std.Dev. & Min & Max \\
\hline Portfolio at Risk > 30 days Ratio & PAR30 & 60 & $8.29 \%$ & $2.48 \%$ & $4.36 \%$ & $14.54 \%$ \\
Exchange rate (HTG/USD) & EXR & 60 & 79.23 & 15.26 & 62.2 & 119.7 \\
Inflation rate & INFL & 60 & $1.36 \%$ & $0.66 \%$ & $-1.20 \%$ & $3.30 \%$ \\
Loan Amount per Borrower (in USD) & LAB & 60 & 1386 & 558 & 762 & 3481 \\
Gross Loan Portfolio (in Million USD) & GLP & 60 & 110.24 & 29.96 & 67.94 & 201.03 \\
\hline
\end{tabular}

Source: Author's own calculation from R Software.

$3.30 \%$, with an average of $1.36 \%$ monthly. This shows that the Haitian economy is characterized by a relative high level of inflation rate during the period under study. When it comes to the specific factors of the sample MFIs, on average, the loan amount extended to borrowers is USD 1386. Except MFI1 has an average loan lower than this average. The lowest and the highest loan amounts per borrower are USD 762 and USD 3481. These amounts are adversely affected by the depreciation of the local currency, since the loan amounts are originated in Haitian Gourdes (HTG). Furthermore, the average value for the size of the loan portfolio is USD 110.24 million. However, a substantial difference is observed in the size of the individual MFIs. MFI4 (USD 41.56 million) has the highest average size of loan portfolio. It is followed by MFI3 (USD 37.98 million). MFI2 (USD 10.21 million) has the lowest average size of loan portfolio. Overall, the size of the loan portfolio of the sample MFIs has evolved between USD 67.94 million to USD 201.03 million during the period under study.

\subsection{Estimation Results}

\subsubsection{Analysis of OLS Regression of All MFIs}

Table 3 shows the results of the OLS regression analysis of the sample MFIs. The outputs indicate that the two macroeconomic variables (Exchange rate and inflation rate) are positively correlated with the PAR30 ratio of the sample MFIs. However, since their respective $p$-value $(0.484$ and 0.212$)$ is larger than 0.05 , which is usually considered a good cut-off point, they do not have a statistically significant relationship with the PAR30 ratio. However, their positive coefficients probably indicate that a depreciation of the local currency and an increase in the inflation rate would harmfully impact the loan portfolio quality of MFIs in Haiti. This might be related to the fact that the depreciation of the local currency might result in reducing the purchasing power of the consumers whom the wages are in Haitian Gourdes. As mentioned previously, this depreciation might also imply an increase in the price of imported goods, reducing the economic activities and as a result affecting adversely the borrowers' repayment capacity. Nevertheless, it is convenient to note that a relative significant part of the Haitian population lives from remittances to whom the depreciation of the local currency would benefit, by providing them with more units of Gourdes. But it seems that this is not enough to compensate the adverse effects, since the depreciation 
Table 3. OLS regression analysis of All MFIs.

\begin{tabular}{ccccc}
\hline Variable & Coefficient & Std. Error & $\mathbf{t}$ value & $\operatorname{Pr}(>|\mathbf{t}|)$ \\
\hline Intercept & -15.20234 & 1.50855 & -10.077 & $4.23 \mathrm{e}-14^{\star * *}$ \\
Exchange rate (HTG/USD) & 0.15386 & 0.21845 & 0.704 & 0.484 \\
Inflation rate & 0.11433 & 0.09061 & 1.262 & 0.212 \\
Loan Amount per Borrower (in USD) & -0.08800 & 0.13665 & -0.644 & 0.522 \\
Gross Loan Portfolio (in USD) & 0.81473 & 0.16978 & 4.799 & $1.26 \mathrm{e}-05^{\star * *}$ \\
$\mathbf{R}$ & $\mathbf{R}^{2}$ & $p$-value & & \\
0.6939 & 0.6716 & $1.463 \mathrm{e}-13$ & & \\
\hline
\end{tabular}

Source: Author's own calculation from R Software.

is not supported by the exportations. In addition, an increasing level of inflation would possibly limit consumers' ability to make purchases, as the amount of goods and services would be consequently restricted. Since borrowers could not easily turn their goods over to generate enough revenues, their repayment capacity would be adversely affected.

Concerning the specific factors to the MFIs, in contrast to the expected effect, the loan amount per borrower has a negative relationship with the PAR 30 ratio, indicating that an increase of $1 \%$ in the loan amount per borrower would possibly imply a decrease of $0.09 \%$ in the PAR30 ratio. This result is in contrast to Pal and Mitra (2017). But, with a p-value of 0.522 (greater than 0.05), its relationship with the PAR30 ratio is statistically insignificant. Conversely, the coefficient of the gross loan portfolio is positive and strongly statistically significant at $1 \%$ lev$\mathrm{el}$, with a p-value of $1.26 \mathrm{e}-05$. An increase of $1 \%$ in the gross loan portfolio of the MFIs would imply a deterioration of about $0.81 \%$ of their PAR30 ratio, other things constant. This means, as the size of gross portfolio increases, the loan portfolio quality might deteriorate. This finding is consistent with Pal and Mitra (2017) and in contrast to (Tehulu \& Abegaz, 2016).

\subsubsection{Analysis of OLS Regression of of MFI1}

Table 4 displays the results of the OLS regression analysis of MFI1. The exchange rate has a positive and statistically significant relationship with the loan portfolio quality of MFI1 at $10 \%$ level. This means as the exchange rate increases, the loan portfolio quality would deteriorate. An increase of $1 \%$ in the exchange rate would result in about $0.70 \%$ of increase in the PAR30 ratio. The positive coefficient of the inflation indicates a positive relationship with the loan portfolio quality. But this is not statistically significant with a p-value greater than 0.05 . As expected, the loan amount per borrower is positively and statistically associated with the portfolio at risk at $5 \%$ level. An increase of $1 \%$ in the loan amount per borrower might imply an increase in the portfolio at risk over 30 days of about $0.80 \%$. This output is in line with Pal and Mitra (2017). As well, an increase in the gross loan portfolio of MFI1 would put more assets at risk. However, this is statistically insignificant. 
Table 4. OLS regression analysis of MFI1.

\begin{tabular}{ccccc}
\hline Variable & Coefficient & Std. Error & $\mathrm{t}$ value & $\operatorname{Pr}(>|\mathrm{t}|)$ \\
\hline Intercept & -17.25557 & 2.75931 & -6.254 & $6.25 \mathrm{e}-08^{\star * *}$ \\
Exchange rate (HTG/USD) & 0.69769 & 0.27836 & 2.506 & $0.01518^{*}$ \\
Inflation rate & 0.05091 & 0.11415 & 0.446 & 0.65735 \\
Loan Amount per Borrower (in USD) & 0.80463 & 0.27213 & 2.957 & $0.00457^{\star *}$ \\
Gross Loan Portfolio (in USD) & 0.20950 & 0.27590 & 0.759 & 0.45089 \\
$\mathbf{R}$ & $\mathbf{R}^{2}$ & $p$-value & & \\
0.5857 & 0.5555 & $5.13 \mathrm{e}-10$ & & \\
\hline
\end{tabular}

Source: Author's own calculation from R Software.

\subsubsection{Analysis of OLS Regression of MFI2}

As indicated in Table 5, the loan amount per borrower and the gross loan portfolio have a positive coefficient. These are statistically and significantly associated with the loan portfolio quality of MFI2 respectively at 5\% level and 10\% level. This means an increase of these two factors would imply more risk for MFI2. This result is in contrast to the output of Loan amount per borrower for the whole sample MFIs and confirms that the credit risk increases as the gross loan portfolio increases. In addition, the exchange rate is positively associated with the PAR30 ratio, but statistically insignificant. Conversely, the inflation rate is related negatively to the loan portfolio quality. This suggests that an increase in the inflation rate would possibly imply a decrease in the credit risk of MFI2. This result is consistent with Hitchcock (2014). This might be related to the fact that MFI2 would intensify its collection activities during periods of inflation. Or the borrowers of MFI2 adjust accordingly the price of goods and services by taking advantage of high inflation by diversifying their investments, especially as borrowers of MFI2 are typically Small and Medium Enterprises (SMEs) compared to the other MFIs under study which serve both Micro and SMEs.

\subsubsection{Analysis of OLS Regression of MFI3}

As MFI1, the exchange rate has a positive and significant relationship with the loan portfolio quality of MFI3 at 5\% level, indicating that an increase in the exchange rate will imply more credit risk (Table 6). An increase of $1 \%$ in the exchange rate will result in an increase of approximately $0.85 \%$ of the PAR 30 ratio. In addition, the inflation rate is correlated with the PAR30 ratio, but not statistically. On the contrary, MFI3 is the only MFI under study of which the gross loan portfolio is negatively related to the loan portfolio quality, even the coefficient is found statistically insignificant. This suggests that as the size of the loan portfolio rises, the portfolio quality would possibility improve. This result is consistent with Tehulu and Abegaz (2016). This finding indicates that the growth of the loan portfolio will not necessarily lead to an increase of credit risk, as long as the borrower selection is carried out properly and credit collection is suitable. 
Table 5. OLS regression analysis of MFI2.

\begin{tabular}{ccccc}
\hline Variable & Coefficient & Std. Error & $\mathrm{t}$ value & $\operatorname{Pr}(>|\mathrm{t}|)$ \\
\hline Intercept & -23.82190 & 3.30415 & -7.210 & $1.71 \mathrm{e}-09^{\star * *}$ \\
Exchange rate (HTG/USD) & 0.36693 & 0.43482 & 0.844 & 0.40239 \\
Inflation rate & -0.08684 & 0.16147 & -0.538 & 0.59288 \\
Loan Amount per Borrower (in USD) & 0.79759 & 0.28768 & 2.772 & $0.00758^{* *}$ \\
Gross Loan Portfolio (in USD) & 0.65719 & 0.27508 & 2.389 & $0.02035^{*}$ \\
$\mathbf{R}$ & $\mathbf{R}^{2}$ & $p$-value & & \\
0.5136 & 0.4782 & $3.741 \mathrm{e}-08$ & & \\
\hline
\end{tabular}

Source: Author's own calculation from R Software.

Table 6. OLS regression analysis of MFI3.

\begin{tabular}{ccccc}
\hline Variable & Coefficient & Std. Error & $\mathbf{t}$ value & $\operatorname{Pr}(>|\mathbf{t}|)$ \\
\hline Intercept & -5.19809 & 1.72131 & -3.020 & $0.00383^{* *}$ \\
Exchange rate (HTG/USD) & 0.85176 & 0.26266 & 3.243 & $0.00201^{* *}$ \\
Inflation rate & 0.03589 & 0.10210 & 0.352 & 0.72654 \\
Loan Amount per Borrower (in USD) & 0.18875 & 0.10196 & 1.851 & 0.06952. \\
Gross Loan Portfolio (in USD) & -0.23317 & 0.19063 & -1.223 & 0.22651 \\
$\mathbf{R}$ & $\mathbf{R}^{2}$ & $p$-value & & \\
0.4895 & 0.4524 & $1.35 \mathrm{e}-07$ & & \\
& & & &
\end{tabular}

Source: Author's own calculation from R Software.

\subsubsection{Analysis of OLS Regression of MFI4}

In contrast to the findings of the other 3 MFIs, the results of MFI4 denote that the exchange rate is negatively associated with the loan portfolio quality. But the coefficient is not statistically significant. This shows that as the local currency depreciates, the credit risk would possibly decline (Table 7). This also indicates that the depreciation of the Haitian Gourdes would not necessarily lead to an increase in the PAR30 ratio, if the rise of the exchange rate does not cause for instance inflation, thus any reduction of the purchasing power of the consumers. In addition, the customers of the borrowers of MFIs who receive remittances would have more revenues as long as the local currency depreciates. This would stimulate the economic activity and as a result would improve borrower's capacity to repay their loans. In contrast to the other MFIs under study, the estimates for MFI4 suggest that as the loan amount per borrower rises, the portfolio quality would improve. The coefficient is statistically significant at $5 \%$ level. An increase of $1 \%$ in the loan amount would lead to a decrease of approximately $0.42 \%$ in the PAR30 ratio. This might be related to an appropriate assessment of the repayment capacity and creditworthy of borrowers, implying that the amount disbursed will not contribute to over-indebtedness. In addition, the amount granted satisfies adequately borrowers' financing needs. Paradoxically, the growth of the loan portfolio would contribute to increase the delinquency level, if appropriate collection policy and practices are not implemented. The coefficient is strongly 
statistically significant at $1 \%$ level. A growth of $1 \%$ in the size of loan portfolio infers approximately $1.31 \%$ of increase in the portfolio at risk.

\subsection{OLS Regression Diagnostics: Multicolinearity}

Multicollinearity is defined as a situation where two or more independent variables in a multiple regression model are related to each other and as well associated with the dependent variable. Perfect multicollinearity indicates that the correlation between two independent variables is equal to 1 or -1 . Generally, the issue of multicollinearity occurs when there is an approximate linear relationship among two or more independent variables. Multicollinearity inflates uselessly the standard errors of the coefficients. Thus, multicollinearity makes some variables statistically insignificant when they might be significant. On the other hand, without multicollinearity, i.e., with lower standard errors, those independent variables might be statistically significant. The variance inflation factor (VIF) is usually applied to detect multicollinearity. This measures how much the variance of an estimated regression coefficient increases when self-governing variables are correlated. As a rule of thumb, a VIF is considered to be problematic when its value is greater than 10 (Hair et al., 1995; Shrestha, 2020). Table 8 shows the VIFs calculated for all of the independent variables. All of the values are less than 10 . So, we can assume that the results of the models are reliable and the statistically significant variables can influence the loan portfolio quality of MFIs in Haiti.

Table 7. OLS regression analysis of MFI4.

\begin{tabular}{ccccc}
\hline Variable & Coefficient & Std. Error & $\mathbf{t}$ value & $\operatorname{Pr}(>|\mathbf{t}|)$ \\
\hline Intercept & -16.0394 & 1.5083 & -10.634 & $5.90 \mathrm{e}-15^{* * *}$ \\
Exchange rate (HTG/USD) & -0.2547 & 0.3126 & -0.815 & 0.41872 \\
Inflation rate & 0.1853 & 0.1293 & 1.433 & 0.15758 \\
Loan Amount per Borrower (in USD) & -0.4208 & 0.1375 & -3.060 & $0.00342^{* *}$ \\
Gross Loan Portfolio (in USD) & 1.3126 & 0.1615 & 8.129 & $5.37 \mathrm{e}-11^{* * *}$ \\
$\mathbf{R}$ & $\mathbf{R}^{2}$ & $\boldsymbol{p}$-value & & \\
0.6627 & 0.6382 & $2.012 \mathrm{e}-12$ & & \\
\hline
\end{tabular}

Source: Author's own calculation from R Software.

Table 8. VIF values of all the explanatory variables used in the study.

\begin{tabular}{cccccc}
\hline Variable & All MFIs & MFI1 & MFI2 & MFI3 & MFI4 \\
\hline Exchange rate (HTG/USD) & 3.45 & 2.92 & 3.71 & 3.63 & 3.39 \\
Inflation rate & 2.31 & 1.91 & 1.99 & 2.14 & 2.26 \\
Loan Amount per Borrower (in USD) & 6.19 & 2.22 & 1.99 & 5.03 & 5.06 \\
Gross Loan Portfolio (in USD) & 5.54 & 2.43 & 2.07 & 5.67 & 3.98 \\
\hline
\end{tabular}

Source: Author's own calculation from R Software. 
In short, the results suggest that portfolio at risk of MFIs can increase with the depreciation of local currency and as the inflation rises; but the results are not statistically significant. However, individually, the findings of MFI1 and MFI3 show a positive and statistically significant relationship with the exchange rate, while the finding of MFI4 shows a negative and insignificant association with the exchange rate. Solely the result of MFI2 indicates a negative and insignificant correlation between the loan portfolio quality and the inflation rate. Furthermore, the growth of the loan portfolio impacts adversely and significantly the loan portfolio at risk of MFIs globally and individually, except MFI3 that shows a negative and insignificant association with the gross loan portfolio. Among the four MFIs, only the result of MFI4 suggests that the loan portfolio quality would significantly improve as the amount disbursed per borrower rises. Conversely, for the remainder of MFIs, as the loan amount grows, the PAR30 would increase.

\section{Conclusion}

The Haitian MFIs play a critical role in ensuring that the financially excluded people and MSMEs have access to financial services. Despite their contribution to the economy, these MFIs continue to cope with deteriorating loan portfolio quality, which adversely affected their financial performance and can consequently influence their financial sustainability. Based on this rationale, this paper examines factors affecting loan portfolio quality of MFIs in Haiti, using a sample of four non-cooperative MFIs (MFI1, MFI2, MFI3 and MFI4) applying the individual lending methodology. This study uses portfolio at risk over 30 days (in \%) as a measure of loan portfolio quality, two macroeconomic independent variables (exchange rate and inflation rate) and two specific independent variables to MFIs (Loan amount per borrower and gross loan portfolio). Monthly data collected over the period of October 2016 to September 2021 were considered, resulting in a sample of 60 observations for each variable. Under the OLS regression method, five statistical models have been specified: one for all MFIs and one for each MFI individually. Globally, the results show that portfolio at risk of MFIs can increase with the depreciation of local currency and as the inflation rises; but the results are statistically insignificant. Though, at the individual level, the findings of MFI1 and MFI3 indicate a positive and statistically significant association with the exchange rate, while the output of MFI4 suggests a negative and insignificant relationship with the exchange rate. This suggests that, as the exchange increases, MFI4's portfolio quality would possibly improve. Only the result of MFI2 indicates a negative and insignificant relationship between the loan portfolio quality and the inflation rate, suggesting that portfolio at risk would possibly decrease with higher inflation rate. On the other hand, the growth of the gross loan portfolio affects adversely and significantly the loan portfolio at risk of MFIs globally and individually, except MFI3 that indicates a negative and insignificant association with gross loan portfolio. Among the four 
MFIs, only the finding of MFI4 suggests that the loan portfolio quality would strongly and significantly improve as the amount disbursed per borrower increases. This might be related to existing policies and practices in terms of credit analysis to better assess borrowers' real repayment capacity.

Our findings have implications for both authorities and MFIs managers. Authorities should create a promising macroeconomic environment that would help MFIs to limit their credit risk. Policies should boost sectors that are oriented towards the exportations, in order to enhance the export competiveness. To do so, issues such as lack of productivity, too high public deficits or poorly controlled inflation should be addressed. A deterioration of the local currency which is not accompanied by a growth of the national production might adversely influence the economy and consequently the loan portfolio quality of MFIs. This can imply that inflation affects critically the purchasing power of those who perceive their wages in local currency. Moreover, MFIs should reinforce their credit analysis, collection procedures and practices when deciding to expand their loan portfolio, without hindering its quality. Among others, MFIs could develop statistical credit scoring models or strengthen the existing ones, in order to optimize borrowers' selection regarding credit risk profile. The enhancement of the use of information from the national credit information bureau would be very useful in avoiding bad payers and over-indebted borrowers.

To the author's knowledge, this paper constitutes the first to provide Haitian empirical evidence on the relationship between macroeconomic and micro factors and loan portfolio quality of MFIs. The results will be very suitable to academia and will also serve as a reference point for future studies that would estimate loan portfolio quality modelling. For instance, future research might focus on estimating short and long run relationships between the same factors under study with loan portfolio quality of MFIs, using another statistical method. This would help address a methodological gap. As well, future studies might be interested in examining the effects of macrocosmic factors, such as exchange rate and inflation on loan portfolio quality, using a qualitative methodology through direct interviews with borrowers. This would help better understand how their businesses are really affected by exchange rate fluctuations and inflation.

\section{Conflicts of Interest}

The author declares no conflicts of interest regarding the publication of this paper.

\section{References}

Adugna, S. (2014). Determinants of Microfinance Institutions Loan Portfolios Quality: Empirical Evidence from Ethiopia. Addis Ababa University Working Paper.

Agasha, E., Monametsi, G., \& Feela, T. (2020). Loan Portfolio Quality of Microfinance Institutions in Uganda: A Qualitative Assessment. Journal of Financial Risk Management, 9, 155-177. https://doi.org/10.4236/ifrm.2020.92009

Akinlo, O., \& Emmanuel, M. (2014). Determinants of Non-Performing Loans in Nigeria. 
Accounting \& Taxation, 6, 21-28.

Armendáriz, B., \& Morduch, J. (2000). Microfinance beyond Group Lending. Economics of Transition and Institutional Change, 8, 401-420. https://doi.org/10.1111/1468-0351.00049

Berger, A. N., \& Udell, G. F. (1995). Relationship Lending and Lines of Credit in Small Firm Finance. The Journal of Business, 68, 351-381. https://doi.org/10.1086/296668

Bitok, S. K., Cheboi, Y. J., \& Kemboi, A. (2020). Does Portfolio Quality Influence Financial Sustainability? A Case of Microfinance Institutions in Kenya. Asian Journal of Business Environment, 10, 37-43. https://doi.org/10.13106/jbees.2020.vol10.no1.37

Chikalipah, S. (2018). Credit Risk in Microfinance Industry: Evidence from Sub-Saharan Africa. Review of Development Finance, 8, 38-48. https://doi.org/10.1016/j.rdf.2018.05.004

Ciguino, H., \& Paul, B. (2016). Microfinance et performance financière des microentreprises en Haïti. Études Caribéennes, No. 35, 1-11.

Ciguino, H., \& Paul, B. (2021). Analyse de l'impact des programmes de microfinance dans la performance des microentreprises. Collection Economie et Développement (ECODEV)/ Université Quisqueya. Port-au-Prince, Haiti.

Conning, J., \& Morduch, J. (2011). Microfinance and Social Investment. Annual Review of Financial Economics, 3, 407-434.

https://doi.org/10.1146/annurev-financial-102710-144909

Convergences (2019). Microfinance Barometer 2019. 10th Edition. https://www.convergences.org/en/104906-2/

DAI Finance Inclusive (2019). Quarterly Performance Report. Year 3, Fiscal Year 2019-Q2. USAID Haiti.

Daly, S., \& Frikha, M. (2016). Banks and Economic Growth in Developing Countries: What about Islamic Banks? Cogent Economics \& Finance, 4, Article ID: 1168728. https://doi.org/10.1080/23322039.2016.1168728

Dewez, D., HornWelch, K., \& Devaney, P. (2003). Accion Poverty Outreach Findings: MFI4, Haiti. ACCION InSight Series, No. 8.

https://papers.ssrn.com/sol3/papers.cfm?abstract id=906583

Dung, P. T. (2020). Determinants of Loan Repayment Performance of Microbusiness Borrowers in Vietnam. Vietnam National University, Vietnam Japan University.

Fabozzi, F., Gupta, F., \& Markowitz, H. (2002). The Legacy of Modern Portfolio Theory. The Journal of Investing, 11, 7-22. https://doi.org/10.3905/joi.2002.319510

Francis, J., C., \& Kim, D. (2013). Modern Portfolio Theory: Foundation, Analysis and New Development (1st ed.). John Wiley \& Sons, Inc.

Hair, J. F., Anderson, R. E., Tatham, R. L., \& Black, W. C. (1995). Multivariate Data Analysis (3rd ed.). Macmillan.

Harhoff, D., \& Körting, T. (1998). Lending Relationships in Germany-Empirical Evidence from Survey Data. Journal of Banking \& Finance, 22, 1317-1353. https://doi.org/10.1016/S0378-4266(98)00061-2

Heiden, S., Klein, C., \& Zwergel, B. (2013). Beyond Fundamentals: Investor Sentiment and Exchange Rate Forecasting. European Financial Management, 19, 558-578. https://doi.org/10.1111/j.1468-036X.2010.00593.x

Hitchcock, J. (2014). Determinants of Microfinance Loan Performance and Fluctuation over the Business Cycle. Haverford College, Haverford, United States.

Hulme, D., \& Mosley, P. (1996). Finance against Poverty, 1 and 2. Routledge. 
Jote, G. G. (2018). Determinants of Loan Repayment: The Case of Microfinance Institutions in Gedeo Zone, SNNPRS, Ethiopia. Universal Journal of Accounting and Finance, 6, 108-122. https://doi.org/10.13189/ujaf.2018.060303

Julien, L., \& Cadet, L. R. (2013). Microfinance in Haiti: Do the Poorest Have Access to Credit? Conference Paper Presented at the 3rd European Research Conference on Microfinance, June 2013. University of Agder, Norway. https://www.researchgate.net/publication/259693882

Keshtgar, N., Pahlavani, M., \& Mirjalili, S. H. (2020). The Impact of Exchange Rate Volatility on Banking Performance (Case of Iran). International Journal of Business and Development Studies, 12, 39-56.

Khemraj, T., \& Pasha, S. (2009). The Determinants of Non-Performing Loans: An Econometric Case Study of Guyana. MPRA Paper, University Library of Munich.

Leeth, J. D., \& Scott, J. A. (1989).The Incidence of Secured Debt: Evidence from the Small Business Community. Journal of Financial and Quantitative Analysis, 24, 379-394. https://doi.org/10.2307/2330818

Lustin, D. (2005). La microfinance et son rôle potentiel dans l'allègement de la pauvreté et le développement en Haïti. Commission Economique pour l'Amérique Latine et les Caraibes (CEPALC).

Mangram, M. E. (2013). A Simplified Perspective of the Markowitz Portfolio Theory. Global Journal of Business Research, 7, 59-70. https://ssrn.com/abstract $=2147880$

Markowitz, H. (1952). Portfolio Selection. The Journal of Finance, 7, 77-91. https://doi.org/10.1111/j.1540-6261.1952.tb01525.x

MicroRate (2014). Technical Guide: Performance and Social Indicators for Microfinance Institutions. http://www.microrate.com/

Mikir, M., \& Milkessa, A. (2020). Determinants of Loan Repayment Performance of Omo Microfinance Institution: In the Case of Mizan Aman Town, Southwest Ethiopia. Research Journal of Business Management, 14, 7-14. https://doi.org/10.3923/rjbm.2020.7.14

Necesito, N. T. (2016). Testing the Portfolio Risk in Philippine Microfinance Institutions. Asia-Pacific Social Science Review, 16, 32-45.

Pal, D., \& Mitra, S. K. (2017). Does the Number of Borrowers per Loan Officer Influence Microfinance Institution Asset Quality? A Stochastic Frontier Analysis. Investigación Económica, 76, 81-103. https://doi.org/10.1016/j.inveco.2016.11.007

Papias, M. M., \& Ganesan, P. (2009). Repayment Behavior in Credit and Savings Cooperative Societies: Empirical and Theoretical Evidence from Rural Rwanda. International Journal of Social Economics, 36, 608-625. https://doi.org/10.1108/03068290910954059

Paul, B., Garrabé, M., \& Daméus, A. (2011). Impact de la politique d'octroi de crédits sur les comportements des emprunteurs: Étude de cas de l'intermédiation microfinance en Haïti. Management \& Avenir, No. 46, 298-318.

Pfaff, B. (2012). Financial Risk Modelling and Portfolio Optimization with R. John Wiley \& Sons. https://doi.org/10.1002/9781118477144

Schreiner, M. (1999). A Scoring Model of the Risk of Costly Arrears at a Microfinance Lender in Bolivia. Center for Social Development, Washington University in St. Louis. http://www.microfinance.com

Setargie, S. (2013). Credit Default Risk and Its Determinants of Microfinance Industry in Ethiopia. Ethiopian Journal of Business and Economics, 3, 21 p.

Shingjergji, A. (2013). The Impact of Macroeconomic Variables on the Non-Performing Loans in the Albanian Banking System during 2005-2012. Academic Journal of Inter- 
disciplinary Studies, 2, 335-339.

Shrestha, N. (2020). Detecting Multicollinearity in Regression Analysis. American Journal of Applied Mathematics and Statistics, 8, 39-42. https://doi.org/10.12691/ajams-8-2-1

Singh, S. (2018). Microfinance and the Mirage of Women's Empowerment. E-International Relations.

Stiglitz, J. E., \& Weiss, A. (1981). Credit Rationing in Markets with Imperfect Information. The American Economic Review, 71, 393-410. http://www.jstor.org/stable/1802787

Teferi, O. (2019). Determinants of Microfinance Institutions Loan Portfolios Quality: Empirical Evidence from Ethiopia. European Journal of Business and Management, 11, 19-23.

Tehulu, T. A., \& Abegaz, T. M. (2016). Determinant Factors in Credit Risk Management of Microfinance Institutions in Ethiopia. Journal of Policy and Development Studies, 10, 118-129. https://doi.org/10.12816/0032103

Vogelgesang, U. (2003). Microfinance in Times of Crisis: The Effects of Competition, Rising Indebtedness, and Economic Crisis on Repayment Behavior. World Development, 31, 2085-2114. https://doi.org/10.1016/j.worlddev.2003.09.004

World Bank (2021). World Development Report 2021: Data for Better Lives. https://www.worldbank.org/en/publication/wdr2021 